\title{
ТРАГІЧНІ І ТРАВМАТОГЕННІ НАСЛІДКИ РАДЯНСЬКОЇ ПОЛІТИКИ В ГАЛУЗІ УКРАЇНСЬКОЇ ЛІТЕРАТУРИ
}

\author{
Людмила Сірик \\ Університет Марії Кюрі-Склодовської, Люблін, Польща \\ ORCID: 0000-0002-1957-2290
}

\begin{abstract}
Анотація: У статті розглядаються наслідки радянської політики періоду 1922-1991 років в українській національній літературі. Трагічні і травматогенні наслідки реалізованої політики щодо згаданої літератури простежуються на трьох рівнях культурної травми, а саме: а) в індивідуальній біографії та творчості представників літератури, б) на тлі суспільної спільноти українців, в) у макросуспільній площині. Ці проблеми сприяють формуванню травматогенних чинників, які у свою чергу негативно впливають на розвиток, якість і популяризацію української літератури.
\end{abstract}

Ключові слова: радянська політика, українська література, тоталітаризм, травма, фальсифікація.

Літературна політика радянської влади в 1922-1991 роках мала фатальний вплив на зміст і стан української літератури, а також на їі образ у науці та суспільній думці. Вона зумовила безліч трагічних фактів і нанесла травму, яка до сьогодні ятриться на тілі національної літератури. Ця травма становить значну складову частину багатовимірної культурної травми українського народу зокрема і України в цілому. Наслідки травми мають своє негативне продовження, засвідчуючи реалізацію максими про те, що зло породжує нове зло. У даному випадку „травмою” називаємо негативні наслідки глибоких суспільно-культурних змін, які охоплюють багато галузей життя. Травматогенний характер мають несподівані, швидкі, нестримні, радикальні зміни, які шокують суспільство, травмують кардинальні для національної спільноти цінності, засади, звичаї чи переконання. Далеко посунуті зміни приносять також травматогенні чинники (негативні дії та явища) в майбутньому. Сформульовану в статті тезу про те, що згадана політика спричинила в українській літературі травму та появу травматогенних чинників, спробуємо довести, спираючись на історико-літературні, суспільно-політичні, соціологічні та біографічні факти. 
У політиці радянської влади щодо української культури, зокрема літератури, можна виділити п'ять етапів, а саме: I - ліберальна політика у 1922-1929 pр., II - сталінський терор у тридцятих роках, III - дволикість політики у 1940-1953 рр., тобто маніпулювання категоріями патріотизму і націоналізму залежно від суспільно-політичної ситуації; IV „хрущовська відлига” (1956-1968), тобто десталінізація і послаблення „паралічу страху” й одночасно різні форми ворожих дій державних органів проти початків дисидентського руху; $\mathrm{V}$ - відкриті або замасковані дії органів радянської влади в 1969-1991рр. проти самостійного розвитку української літератури і науки про неї.

У ситуації ліберальної політики в першому періоді розпочався розвиток української літератури. Дійшла до голосу творчість представників різних мистецько-художніх напрямів, зокрема символізму, футуризму, неокласицизму, імпресіонізму, неоромантизму. Дозволено на діяльність Української Академії Наук (УАН), функціонування численних видавництв, незалежних від аспірацій влади літературних угруповань, зокрема таких як: Аспис (Асоціація письменників), Ланка (створена 1924 р., у 1926 р. змінила назву на МАРС (Майстерню Революційного Слова), Нова генерація, ВАПЛІТЕ (Вільна Академія Пролетарської Літератури). Роки 1922-1929 ввійшли в історію як період українського культурного відродження. Брак офіційної цензури зумовив активізацію української творчої інтелігенції. Однак політика лібералізації мала свою неоднозначну стратегію і прагматичну мету. Хоч на державному рівні офіційно було проголошено право на свободу творчості і вільний розвиток української літератури, однак фактично державний уряд цьому протистояв. Він діяв за посередництвом літературних та інших організацій, які сам створив. 3 метою втілення своєї доктрини застосував політику українізації в галузі культури, освіти та інших суспільних сферах, а також політику НЕП-у, тобто нову економічну політику щодо селянства та дрібних приватних підприємців. Завдяки цій стратегії уряд притягнув на свій бік всі суспільні прошарки. Політика українізації, якою за наказом уряду керували українські комуністи (Влас Чубар, Микола Скрипник, Олександр Шумський), стала способом на демонстрування лояльності уряду щодо народної традиції і водночас засобом пропаганди радянської ідеології за посередництвом української мови. Проводячи ліберальну політику та ліквідацію неписьменності, уряд СРСР проводив ідеологічний контроль і здобув час на зміцнення своєї влади. Однак вже в другій половині двадцятих років він почав наступ на своїх ідеологічних супротивників, внаслідок чого затримався процес літературного життя і мистецького розвитку. Хоч резолюція в справі літератури і преси, яку оголосив ЦК партії 18 червня 1925 року, формально твердила про лояльність до ідеологічно незалежних організацій і про брак фаворизування якихось конкретних 
літературних угруповань, але в дійсності вже в 1925-1927 роках щораз більше посилювався контроль тих, які не визнавали партійної лінії. Особливо чітко це виявилось під час літературної дискусії 1925-1928 років, коли тривала полеміка навколо питання про культурні орієнтири української літератури. Наріжним каменем дискусії була дилема: орієнтація на літературу західноєвропейської класики чи на російську, іншими словами на „Захід” чи „Схід”, de facto на „Свропу” чи „Росію”. Проурядові органи визнали головними ворогами тзв. „європеїстів” (зокрема київських неокласиків і Миколу Хвильового). Хоч останні трактували поняття „Європа” як категорію культурно-освітню і психологічну, проте уряд сприйняв їхню позицію як спробу відірвати Україну від Росії. У зв'язку 3 цим літературна дискусія прибрала характер політичний: українське письменство звинуватили в державному сепаратизмі. Від 1926 року на „європеїстів” організовано вульгарний публічний наступ. Під кінець двадцятих років посилилась русифікація.

Крім того, у двадцятих роках органи влади різними методами (посадами, застрашуванням тощо) намагалися перетягнути на свою сторону творчі сили. Жертвою такої стратегії стали талановиті митці, у творчій біографії яких чітко увиразнюється трагедія і травматогенні чинники. Яскравим прикладом $€$ постать Павла Тичини. Славу в літературі і в народі принесла йому знаменита збірка Сонячні кларнети (1918), лірика пейзажно-філософська (напр., Ви знаєте як липа шелестить, Хтось гладив ниви) і релігійна (цикли Скорбна мати, Мадонно моя). Однак невдовзі прийнята ним позиція „казенного поета”, що спроваджувалась до виконання державних замовлень, призвела до деградації у мистецькому і моральному вимірах (славнозвісний вірш Партія веде). Зміни в Тичині були разючі, внаслідок чого протягом десятків років кружляли в Україні насмішливі народні пародії типу „Наш Тичина пише вірші та все гірші / Та все гірші / та всі як один/ та всі як один”). Тичина за життя помер як поет і прирік себе на самотність: чужий серед свого народу і чужий в середовищі „двору” радянського офіціозу. Він був покараний славою, про що писав Василь Стус у своїй науковій праці Голгофа слави, присвяченій творчості поета. Безперечно, Тичина відчував і усвідомлював свою трагедію: в окремих творах прочитується його іронія і навіть самоіронія (Мадонно моя...; Сковорода). Протест проти свавільного редагування своїх творів він виявив після смерті Сталіна. У 1954 році йому вдалося відновити ранню редакцію першої строфи триптиха Листи до nоета (,Я комуністка, ходжу в чужому, обрізала косу”), яка у виданнях Bipші й поеми (1950) та Вибрані поезї (1951) мали інший (змінений редакційною цензурою) зміст: „Я комуністка, дивлюсь у майбутнє, обрізала косу”. Покалічених цензурою творів у його письменницькій спадщині $є$ досить багато. Але це тема на окреме опрацювання. Влада зламала Ти- 
чину також і в психологічному вимірі, посіявши в ньому панічний страх. Наприклад, поет сахався автомашин чорного кольору, бо вони викликали асоціацію енкеведистських „воронок”. Він ніколи не заходив у приміщення першим - завжди поступався дорогою іншому. Робив це не тільки 3 чемності. Йому ввижалося, що ззаду його можуть схопити за руки і зв'язати.

Трагічні тридцяті роки сталінського терору (1930-1939) становлять другий етап літературної політики ${ }^{1}$. Згадана вже літературна дискусія в 1925-1928 роках допомогла НКВД (від рос. Народный Комиссариат Внутренних Дел СССР) виявити середовища української інтелігенції народно-патріотичних аспірацій. Широко розгорнуті репресії почалися вже 1929 року: арештовано членів т.зв. „Спілки Визволення України” (СВУ) - фікційної організації, видуманої Головним Політичним Управлінням УРСР. Від 9 березня до 19 квітня 1930 в приміщенні опери в Харкові відбувся показовий процес 45 осіб, звинувачених у керівництві СВУ. Серед головних оскаржених були видатні представники Всеукраїнської Академії Наук (ВУАН), зокрема історик літератури Сергій Єфремов, заступник голови ВУАН, політичний діяч Української Центральної Ради (в 19171918 роках), літературознавці Андрій Ніковський і Володимир Дурдуківський, письменниця Людмила Старицька-Черняхівська. Аж 1989 року КДБ УРСР наново дослідив справу СВУ, стверджуючи відсутність організації, а також реабілітуючи всіх засуджених. Під натиском т.зв. „консолідаційних заходів" з боку компартії всі літературні організації і неформальні угруповання змушені були „самоліквідуватися”. Одночасно розпочалася кампанія проти українських комуністів, котрі сповідували декларовані в теорії комунізму ідеї демократизму та суспільної рівності. Не витримавши психологічного тиску і усвідомлюючи смертоносний арешт, у 1933 році закінчили життя самогубством чільні українські комуністи: нарком освіти України Микола Скрипник і письменник Микола Хвильовий. Це був початок масової ліквідації українського письменства. Згідно зі статистичними даними, у тридцятих роках було розстріляно, закатовано в тюрмах і концтаборах для політичних в'язнів понад 500 письменників і літературознавців, серед них - видатні особистості².

Трагедія ліквідації у тридцятих роках українського письменства національно свідомого і патріотичного спрямування спричинила поширення такого травматогенного фактора, як брак висококваліфікованих кадрів. У літературі їхнє місце зайняли кадрові працівники, які хоч і мали дипло-

Див. м. ін.: Ю. Луцький, Літературна політика в радянській Україні 1917-1934, Київ 2000. [І вид.: Нью-Йорк, Колумбійський університет 1956].

2 Історія української літератури ХХ століття. У двох книгах, кн. I, наук. ред.. В. Дончик, Київ 1994, с. 3. 
ми вищих навчальних закладів, однак були підготовлені по програмі радянського офіціозу. Великою втратою для української освіти в галузі літератури була ліквідація кафедр класичної філології, які готували кадри зі знанням іноземних мов і досягнень європейської класики і теоретичної думки. Інтенцією влади була не художня творчість grand art гуманістичного характеру, а продукція прокомуністичних агіток із застосуванням художнього стилю. Суттєвим виразом загострення державної політики на початку тридцятих років була урядова постанова „О перестройке литературно-художественных организаций”, формально проголошена в квітні 1932 року, згідно з якою підлягали ліквідації всі літературні організації, 3 яких планувалося утворити одну монолітну структуру. На I з'їзді радянських письменників (від 17 серпня до 1 вересня 1934 р.), головним методом радянської літератури визнано соціалістичний реалізм. Політика українізації поступово згорталася під гаслом боротьби з „буржуазним націоналізмом”. Під кінець тридцятих років література була спроваджена до однієї соцреалістичної „ноти”. Хоч формально не інформувалося про скасування українізації, але фактично ії цілком стримано, а всі iii досягнення постійно і цілеспрямовано ліквідовувалися. Письменників та інших представників української культури, які стали жертвами сталінізму, пізніше українське літературознавство національно-визвольних інтенцій назве „Розстріляним Відродженням”з.

Третьому періоду політики влади щодо української літератури (19401953 рр.) характерна стратегія дволикості, зокрема маніпулювання категоріями патріотизму і націоналізму. Ці категорії експлуатовано залежно від суспільно-політичної ситуації та потреб ЦК КПРС. Під час ІІ світової війни, зокрема в 1941-1945 роках, коли треба було побороти фашистських окупантів, партійно-державницький натиск на українську культуру національного характеру ослаб. Тоді в літературній творчості на перший план було висунуто категорію українського патріотизму. 3'явилися присвячені Україні патріотичні вірші відомих поетів (Андрія Малишка, Максима Рильського, Володимира Сосюри, Платона Воронька, Івана Виргана), романи, зокрема Наша молодість Олекси Гуреїва, Його покоління Івана Сенченка, Жива вода Юрія Яновського, новела Навколо полум'я Олександра Копиленка, та інші твори. Проте державне керівництво цією категорією маніпулювало - насправді його пріоритетом був „патріотизм радянський ". Про дволикість політики і пильний контроль української літератури з боку державного апарату свідчить хоча б той факт, що гострі атаки були спрямовані на Олександра Довженка відразу після появи 1943 року його кіноповісті Україна в огні. У цьому творі на тлі смертельної

Розстріляне Відродження. Антологія 1917-1933: поезія - проза - драма - есей, виб. і опрац. Ю. Лавріненко, Київ 2007 [Перше видання Paryż: Instytut Literacki, 1959]. 
боротьби з фашизмом аргументовано й переконливо піднімалися проблеми гуманізації суспільства й людської особистості, засудження війни, а також уперше засуджено положення і вимоги сталінізму. Тому цензура заборонила твір.

Маніпуляції сталінського керівництва чітко виявились невдовзі після закінчення війни, коли воно скерувало свою політику на зміцнення тоталітарного режиму. У липні 1946 року ЦК ВКП (б) ухвалив резолюцію про важливі помилки українських комуністів, закидаючи їм, що не звернули належної уваги на ідеологічно-політичне виховання і кадровий склад в галузі науки, літератури і мистецтва, тому що серед кадрового складу існує „ворожа буржуазно-націоналістична ідеологія”. Услід за рішеннями на центральному рівні ЦК КП(б)У прийняв постанови „Про перекручення і помилки в представленні історії української літератури” (серпень 1946), „Про журнал сатири і гумору «Перець»” (вересень 1946), „Про журнал «Вітчизна»” (вересень 1946), „Про репертуар драматичних і оперних театрів УРСР і заходи щодо його вдосконалення" (вересень 1946). У цих партійних документах українські письменники, літературознавці, історики й артисти були звинувачені в „буржуазному націоналізмі” і цілеспрямованій ігноранції сучасності у своїх текстах. У світлі засад соцреалізму ідеологічній цензурі піддавалося всі часописи, культурно-освітні установи і творчі організації. Під гаслом боротьби „за викорінення всіх решток буржуазно-націоналістичної ідеології” в серпні 1945 року на сторінках преси тривала гостра негативна критика творчості чільних прозаїків (м. ін. Остапа Вишні, Михайла Стельмаха) і поетів (Андрія Малишка, Степана Олійника і ін.). У 1947 році розпочалася друга хвиля „сталінських чисток” (політичні переслідування, оскарження, репресії, депортації тощо ${ }^{4}$.

Ідеологічний контроль і криза морально-політичної ситуації загострилася в період перебування на посаді першого секретаря ЦК КП(б) У Лазаря Кагановича (від березня до грудня 1947 р.), вірного прибічника Сталіна. Тоді українських літераторів відкрито застрашували й ізолювали від культурного національного середовища, адміністративним методом переводили до Москви й інших міст СРСР. Під пильним контролем Кагановича у вересні 1947 року відбулося пленарне засідання керівництва Спілки Письменників України, основною метою якого було гостре засудження тзв. „буржуазних перекручень в творах окремих письменників”. Розгорнулися відкриті публічні напади проти Максима Рильського за поему Мандрівка в молодість, вірш Слово про рідну матір (1941), поетичний цикл Київські октави $і$ за реферати Київ в історії Украйни

\footnotetext{
4 Див. монографію на тему репресій у 30 -тих і на поч. 50-тих років: Ю. Шаповал, $У m i$ трагічні роки: сталінізм на Украӥні, Київ 1990.
} 
та Річниия Шевченка. Лавину гострої критики спрямовано проти Юрія Яновського за роман Жива вода (1947), в якому письменник втілив ідею невмирущості нації, відроджуваної після воєнної катастрофи. Офіціозна критика нещадно критикувала Івана Сенченка за роман Його покоління (1947) [перероблений згідно з вимогами соцреалізму і виданий 1965 р.] та Петра Панча за збірку повістей Голубі ешелони (1928), в якій офіціозна критика вбачала брак суворого класового підходу в зображенні образів „ворогів” радянської влади, недостатнє розвінчання представників „буржуазно-націоналістичної контрреволюціі”. Прозаїка змушено переписати й переакцентувати повість Голубі ешелони в руслі вимог прорадянської ідеології. Спочатку це був психологічний твір, а в переробленій редакції став - сатиричний з елементами гротеску: офіцерів, старшин і рядових петлюрівського війська, членів дипломатичної місії Директорії (зокрема в зображенні дипломатів, їхніх серйозних політичних дискусій) гостро висміювалося.

У третьому періоді своєї політики влада застосувала стратегію вичікування відповідного моменту для нападу на письменство за його ухили від офіціозної лінії. Одним із яскравих фактів такої стратегії були широко закроєні напади на Володимира Сосюру за вірш Любіть Украйну. Це був ніж у спину поета, бо влада радикально змінила своє ставлення до твору. Вірш, написаний 1944 року, одразу було перекладено російською мовою, покладено на музику і його співала вся радянська армія. Натомість у 1951 році вкрай негативно скритиковано за тзв. „український буржуазний націоналізм". Сосюру не тільки публічно оскаржували і обкидали брудом, але й творили навколо нього атмосферу негативного ставлення суспільства. Таким чином, радянське керівництво патріотизм ототожнювало з націоналізмом. Оскарження були сфабриковані, бо фактично поет у своєму творі виразив тільки любов до України як Батьківщини і був цілком далекий від націоналістичної позиції. Відомо, центральною категорією патріотизму є „країна”, а не „нація”. Проте ЦК КПРС і підвладні йому органи та їхні слуги-кар'єристи з верств інтелігенції в галузі літератури трактували патріотизм та інші категорії так, як було для них вигідно. У маніпулюванні категоріями радянський офіціоз виявив свій прагматизм, який мав йому запевнити бажаний суспільний статус і зміцнення влади. Тимчасом українській літературі соцреалістичного напряму характерні були всі риси, які свідчили про мистецьку деградацію і про брак зацікавлення народною проблематикою в гуманістичному плані. Загалом від 1946 до 1951 року було прийнято 12 постанов ідеологічного характеру, які були підставою для атак на всі категорії творчої інтелігенції. Практичне виконання партійних рішень реалізовувалось такими способами, як політична цензура, вкрай негативні й наклепницькі рецензії в пресі, а також судові вироки, які оголошувалися на зборах представників літе- 
ратурних середовищ та інших культурних кіл. Письменників постійно змушували змінювати ідеологічне спрямування творів і навіть публічно зрікатися своїх поглядів.

Послаблення цензури настало тільки після смерті Сталіна (1953 р.) і виступу Микити Хрущова (першого секретаря ЦК КПРС у 1953-1964 pp.) на ХХ з'їзді КПРС 1956 року з рефератом „О культе личности и его последствиях", в якому було скритиковано сталінізм і культ особи. Настав час т.зв. „хрущовської відлиги”, який тривав у 1956-1968 роках. Це був четвертий період радянської політики щодо української літератури. У суспільстві появилася надія на гуманізацію суспільного устрою і реалізацію національних прав, передбачених Конституцією СРСР. У новій ситуації почався процес десталінізації і ослаблення „паралічу страху”. У ході цього процесу виник в другій половині п’ятдесятих років дисидентський рух, який залежно від умов, наростав або зменшувався, триваючи до розпаду радянської імперії в грудні 1991 року. Цей рух презентувала невелика кількість людей різних спеціальностей, яких називали себе дисидентами (від лат. dissideo „протистояти”). Заявило про себе нове покоління української інтелігенції, яке ввійшло в культуру і політику в другій половині п’ятдесятих і найповніше виявило себе на початку шістдесятих років. Від назви десятиліття його названо „шістдесятники”. На відміну від своїх попередників з тридцятих років, вони не боялися виступати проти дискримінації в сфері національної політики, офіційного догматизму, фальсифікації, русифікації, профанації творчості, не боялися складати петиції з метою захисту української культури (в т. ч. мови), проводити неформальні літературні вечори присвячені пам'яті репресованих митців, організовувати читання творів „промовчуваних” i заборонених. Основу руху шістдесятників склали письменники Іван Драч, Микола Вінграновський, Володимир Дрозд, Григір Тютюнник, Ліна Костенко, Василь Стус, Борис Олійник, Валерій Шевчук, літературні критики Іван Дзюба, Євген Сверстюк, режисер Лесь Танюк, кінорежисери Сергій Параджанов і Юрій Іллєнко, кінокритик Роман Корогодський, перекладачі - Григорій Кочур, Микола Лукаш, художники - Алла Горська, Віктор Зарецький, Борис Чичибалін і багато інших митців. Дисиденти становили моральну опозицію проти радянського режиму.

Однак лібералізація в політиці була умовною, а суспільна „відлига” тимчасовою, оскільки у творчій інтелігенції ліберально-демократичної орієнтації партія бачила головну загрозу для своєї диктатури і монополії на владу. Культурна діяльність „шістдесятників” викликала незадоволення влади, оскільки не вписувалась у рамки дозволеного цензурою канону. Вже 17 грудня 1962 року, на спеціальній зустрічі творчої інтелігенції $з$ державним керівництвом, митців піддано гострій критиці. Влада неформально і потаємно почала усувати „надзвичайно небезпечних 
письменників". Одним із прикладів першого способу є створення на вокзалі безпідставної суперечки, арешт і побиття працівниками міліції залізничної станції в містечку Сміла поета Василя Симоненка 1962 року, внаслідок чого він помер у грудні 1963 року в лікарні. Цей злочин було здійснено за опозиційну діяльність поета, зокрема оприлюднення ним, разом з Лесем Танюком і Аллою Горською, фактів масових розстрілів населення у Биківнянському лісі в передмісті Києва. Після усунення Хрущова з посади першого секретаря ЦК КПРС весною 1964 року різко посилився натиск державної цензури на українську творчу інтелігенцію. Після видання постанови ЦК КПРС „О цензуре” (весною 1965 р.) і особливо після введення військ СРСР до Чехословаччини (кінець „Празької Весни") влітку 1968 року уряд Радянського Союзу взяв курс на реставрацію тоталітаризму.

Настав п’ятий період „літературної політики”, що датується роками 1969-1991. У цей час закамуфльованим або відкритим способом реалізовано тоталітарну політику в галузі української культури, зокрема літератури. Протягом 1965-1972 років дисидентський рух „шістдесятників” був розбитий. Лиш незначна частина його представників писала „до шухляди”, вибравши позицію „внутрішньої еміграції”, мовчання (Ліна Костенко, Василь Шевчук). Тим, які надалі протистояли національній дискримінації та русифікації, влада виносила кари арештів і позбавлення свободи на 10, 15 і більше років, тобто ув'язень і невільницької праці в концтаборах (Іван Світличний, Ігор Калинець, Свген Сверстюк і багато інших), де частина з них загинула (Василь Стус, Валерій Марченко). Натомість звільненим цілком заборонено брати участь у літературній праці. У ситуації репресій, застрашувань, шантажу, ув'язнень і заслань, частина письменників і публіцистів без більшого опору перейшла на позицію згідну з офіціозом, дехто відійшов від творчої праці (Борис Мамайсур, Василь Голобородько, Я. Ступак). Івана Дзюбу звільнено з тюрми тоді, коли він, психічно не витримавши натиску, публічно зрікся своїх поглядів, висловлених у памфлеті Інтернаціоналізм чи русифікація? (1965). Ще грізнішим від тюрем видом покарань була репресивна психіатрія - спосіб поневолення політичних опозиціонерів, який полягає на примусовому психіатричному лікуванні в спеціальних психлікарнях, будинках для божевільних із жорстоким режимом, що не поступався тюремному. Тут працювали співробітники КДБ, які за допомогою примусового лікування психотропними препаратами намагалися повернути „на путь истинный” противників радянської ідеології. Застосовувалися препарати для пригнічення волі, психіки, інтелекту, пам'яті, емоцій. Режим ізолював найнебезпечніших для себе вільнодумців, особливо тих, кому не вдавалося приписати ані антирадянщини, ані аморальності. Дисидента поміщали у середовище вбивць та гвалтівників, нерідко під 
наглядом „санітара” з карних злочинців. Серед жертв такого мордування були письменники Леонід Плющ, Василь Рубан, Анатолій Лупинос та інші. Органи влади активно використовували також адміністративні переслідування, зокрема звільнення з роботи, виключення з партії, комсомолу, творчих спілок, навчальних закладів, заборона публікацій тощо. Переслідування поширювалися також на батьків дисидентів, дітей, близьких родичів, друзів. Проти дисидентів влаштовували також провокації (підкидали антирадянську літературу, зброю, наркотики, інспірували згвалтування, побиття і т. ін.). Українські письменники були змушені змінювати ідеологічне спрямування творів і видавати їх в новій редакції, виконувати „державні замовлення”, тобто продукувати тексти за канонами соцреалізму. Інший негативний фактор - це конформізм, який призводив до творчої деградації.

Слід зазначити, що з приводу радянської політики різні генерації українського суспільства не мали доступу до інтелектуальних і мистецьких здобутків Розстріляного Відродження та послідовників його гуманістичних і національно-визвольних ідей. Натомість у суспільній свідомості приживалася різного виду фальсифікація, яку поширювала радянська пропаганда, зокрема соцреалістична літературна критика і засоби масової інформації. Слід зазначити, що фальсифікації дуже вітальні, навіть у наш час. Так, у науковому обігу ще трапляються випадки, коли київських неокласиків зараховують до „чистого мистецтва”, повторюючи твердження соцреалістичної критики ${ }^{5}$. Хоч, як зауважив Володимир Івашко, у хибності цих поглядів нарешті починає упевнюватись українська теоретична думка ${ }^{6}$, проте надалі зустрічаємося 3 повтореннями тверджень щойно згаданої критики. Наприклад, в одній праці, виданій 2004 року, читаємо: „В основі «неокласичного» лежить ідея «чистого мистецтва», котра в тлумаченні Зерова передбачає розуміння літератури передусім як мистецтва, не обтяженого «класовими», «партійними», «ідеологічно-виховними» функціями"7. Цю хибну думку заперечує не тільки творчість і праці неокласиків, а їхні висловлювання під час літературної дискусії 1925-1928 років, яскравим прикладом чого є, зокрема, трактат М. Зерова Ad fontes (1926). У ситуації „хрущовської відлиги” Максим Рильський, як один із членів угруповання київських неокласиків двадцятих років, висловив думку, яка заперечує існуючу фальсифікацію. Він заявив, що „апологетами «чистої краси», «мистецтва для мистецтва»

Див.: Українська Радянська Енцииклопедія: в сімнадцяти томах, т. 10, Київ 1962, с. 59.

6 В. Івашко, Микола Зеров і літературна дискусія (1925-1928), „Слово і час” 1990, № 4, c. 23.

7 В. Башманівський, Художня природа „неокласичного” в поетичній творчості Миколи Зерова, автореф. дис. на здобуття звання канд. філол. наук, Київ 2004, с. 14. 
і тому подібних нісенітниць неокласики себе ніяк не вважали і не проголошували" і що „ніхто з учасників групи ніде й ніколи такого гасла не підносив" До речі, хибний погляд опозиціонерів категорично заперечував сам лідер угруповання М. Зеров у 1926 році: „Неокласики ніколи не погодяться із Загулом, що «мистецтво» існує «ради мистецтва»" 10.

Після розпаду СРСР доступними стали заборонені радянською цензурою джерельні матеріали митців і об'єктивні розвідки деяких діаспорних літературознавців, а також з'явилися в суверенній Україні праці сучасних дослідників, які фахово, без ідеологічних упереджень, намагаються 3'ясувати неокласичну творчість ${ }^{11}$. Проте надалі повторюються фальсифікації, сформовані на державні замовлення, або під тиском радянських органів безпеки і „вірнопідданих”, зокрема кар'єристів. Тенденційні характеристики деформують автентичний образ митців та їхній напрям. Вони розповсюджуються в Інтернеті, а також проникають до нещодавно виданих наукових посібників, у тому числі зарубіжних ${ }^{12}$. Наприклад:

Awangardyści w imię «europeizacji» rodzimej literatury i jej «technicznej doskonałości» chcieli podjąć walkę z «wszelkim epigoństwem», neoklasycyzmem, dekadentyzmem i impresjonalizmem [...]. Poliszczuk [Валер'ян Поліщук - Л. С.] krytykował postawy tzw. «neoklasyków» (M. Zerow, 1890-1941; Draj-Chmara, 1889-1939; M. Mohylanśkyj, 1873-1944; O. Burghardt, 1891-1946; M. Rylśkyj, 1895-1964) i członków WAPLITE (Wolna Akademia Proletariackiej Literatury), którzy określali w rewanżu działalność Poliszczuka mianem «kontrrewolucyjnych wybryków» (ten i inne polityczne donosy stały się jednym z pretekstów do represji, więzień i wyroków śmierci: Semenko i Poliszczuk wraz z dziesiątkami innych pisarzy ukraińskich stali się ofiarami stalinowskiego terroru po prowokacyjnym zabójstwie S. Kirowa w grudniu 1934) ${ }^{13}$.

Аж ніяк не можна погодитися з кількома твердженнями у цій цитаті. По-перше, авангардисти не могли виступати проти неокласицизму, тому саме представники цього напряму в особах київських неокласиків як ніхто інший в українській літературі двадцятих років XX ст. задемонстрували європеїзм і чітко сформулювали концепцію європеїзації української літератури національного спрямування. По-друге, саме неокласики ра-

\footnotetext{
8 М. Рильський Микола Зеров - поет, і перекладач, [в:] М. Зеров, Вибране, Київ 1966. 9 Там само, с. 4.

10 М. Зеров, Наші літературознавиі і полемісти, [в:] Той самий, Украӥнське письменство, упор. М. Сулима, Київ 1990, с. 542.

11 Див. м. ін. Л. Сірик, Прагнення Свропи. Творчість київських неокласиків, Lublin 2013.

12 Див.: G. Gazda, Stownik europejskich kierunków i grup literackich XX wieku, Warszawa 2000, s. 45, 302, 658 .

13 Там само, с. 45.
} 
зом із Миколою Хвильовим як чільним представником ВАПЛІТЕ обстоювали гасло “Ad fontes”, підкреслюючи цінність європейської класики, а також були в опозиції до політики комуністичної влади в галузі літератури. Саме цих митців влада оскаржила в “контрреволюції” і майже всіх фізично ліквідувала. Вони ніколи не доносили на авангардистів і не давали жодних претекстів до арештів чи смерті представників інших мистецьких напрямів. Таким чином, сформульоване в цитаті оскарження фальшиве і тенденційне. Тимчасом багато представників авангарду пішло на співпрацю $з$ державним апаратом влади. По-третє, Валер'ян Поліщук, який не мав класичної освіти, стояв осторонь згаданої вже європеїзації. Крім того свідченням прокомуністичної позиції поета є його співпраця в 1920 році з київською газетою “Більшовик” і членство у літературній організації "Гарт", створеної за ініціативою комуністичної влади. Засноване ним 1925 року модерністське угруповання “Авангард" обстоювало програму конструктивного динамізму, згідно з якою поезія мала оспівувати світ технічної революції та модерну цивілізацію, яка протиставлялася традиційному суспільству. Аргументи можна продовжити, однак це питання вимагає окремого дослідження. 3 огляду на обмежені рамки нинішньої статті нема місця на дискусію щодо поширення в Інтернеті фальсифікацій, зроджених у межах соцреалістичної критики. Існуючий стан свідчить про важкий процес проникання правди до суспільної свідомості навіть тоді, коли цьому вже не загрожують радянські органи безпеки.

$$
* * *
$$

Як бачимо, політика радянської влади спричинила трагедію української літератури. Протягом свого панування влада міняла тоталітарні форми впливу на письменство, трактуючи його утилітарно. У списку цих форм і методів примусу - це масові вироки смерті, концтабори, психлікарні, політична цензура, переслідування, лякання, гостра критика, закамуфльовані та відкриті тоталітарні дії, численні відкриті і тайні постанови, спрямовані на тзв. „викриття українського буржуазного націоналізму”, а в дійсності проти національної літератури, традиції, ідентичності, історичної пам'яті, самосвідомості і формально передбачених державною Конституцією прав. Історія української літератури - це безперервний ланцюг індивідуальних і масових трагедій, трагедій як людських, так і на тлі художнього і наукового доробку, інтелектуально-духовних здобутків. $\mathrm{y}$ різний час, у різних формах і різними способами трагічні факти спричинялися до формування культурної травми українського народу, яка проявляється в суспільно-політичному, ментальному, психологічному і мистецькому вимірах. Трагічні зміни породжували травматогенні чинники, 
які розповсюджувались i, як бактерії, творили свої мутації, атакуючи свідомість і душу. Письменство змушене було до мімікри і служіння інтересам влади. Окрім смерті чи втечі за кордон залишалися дві альтернативи: або існувати із роздвоєним єством, або стати маріонеткою влади. У результаті цього та інших фактів процесу потерпало справжнє літературне мистецтво, відсунуте в тінь, або ще гірше - гинуло в цензурних сейфах, у концтаборах чи полум'ї вогню. Прикметно, сформовані мутації мають травматогенну, тобто хвороботворчу, природу. Вони далі функціонують і заважають загоїти рани та відробити безповоротні втрати так, щоб національна література стала внутрішньою (духовною) потребою, джерелом знань і гуманістичних цінностей українського суспільства, а також осягнула відповідну якість і статус на міжнародному рівні.

Трагічні наслідки радянського тоталітаризму на тлі української літератури - багатоаспектні. Вони відбилися на різних рівнях нанесеної їй травми, а саме: а) в індивідуальній біографії та художній творчості письменників; б) у літературознавстві та в історії і теорії літератури; в) у сфері літературно-мистецьких явищ; г) у сфері творчих організацій і неформальних угруповань. Вони також простежуються на тлі свідомості української нації, українського суспільства і міжнародної спільноти. Словом, травмовано всі кардинальні для національної спільноти цінності, всі прошарки суспільного життя, пов'язані з літературою. Травматогенні зміни можна вважати історичними.

\section{ЛІТЕРАТУРА}

Bašmanìvs'kij Valerìj. 2004. Hudožnâ priroda ,neoklasičnogo» vpoetičnì tvorčostì Mikoli Zerova. Avtoref. dis. na zdobuttâ zvannâ kand. filol. nauk. Kiïv: Kiïvs'kijnacìonal'nij unìversitet ìmenì Tarasa Ševčenka. [Башманівський Валерій. 2004. Художня природа „неокласичного” в поетичній творчості Миколи Зерова. Автореф. дис. на здобуття звання канд. філол. наук. Київ: Київський національний університет імені Тараса Шевченка].

Zerov Mikola. 1990. Naši literaturoznavcì ì polemisti. W: Mikola Zerov. Ukraïns'ke pis'menstvo. Upor. Sulima M. Kï̈v: Osnovi [Зеров Микола. 1990. Наші літературознавиі і полемісти. В: Микола Зеров. Украӥнське письменство. Упор. Сулима М. Київ: Основи].

Ìvaško Volodimir. 1990. Mikola Zerov i literaturna diskusiâ (1925-1928). „Slovo ì čas” $\mathrm{nr}$ 4: 18-27 [Івашко Володимир. 1990. Микола Зеров і літературна дискусія (1925-1928), „Слово і час” № 4: 18-27.]

Luc'kij Ûrìj. 2000. Literaturna polìtika v radâns'kì Ukrä̈nì 1917-1934. Kï̈v: Gelìkon [Луцький Юрій. 2000. Літературна політика в радянській Україні 1917-1934. Київ: Гелікон].

İstoriâ ukraïns'koï literaturi XX stolittâ: U dvoh knigah, kn. I. 1994. Red. Dončik V. Kï̈v: Libìd' [Історія української літератури XX століття: У двох книгах, кн. I. Ред. Дончик В. Київ: Либідь]. 
Ril's'kij Maksim. 1966. Mikola Zerov - poet, i perekladač. V: Zerov M. Vibrane. Kiïv: Dnìpro [Рильський Максим. 1966. Микола Зеров - поет, і перекладач. В: Зеров М. Вибране. Київ: Дніпро].

Rozstrilâne Vidrodžennâ. Antologiâ 1917-1933: poezîa - proza - drama - esej. 2007. Vib. ìoprav. Lavrìnenko Û. Kiïv: Smoloskip [Розстріляне Відродження. Антологія 1917-1933: поезія - проза - драма - есей. 2007. Виб. і оправ. Лавріненко Ю. Київ: Смолоскип].

Sìrik Lûdmila. 2013. Pragnennâ Êvropi. Tvorčist' kï̈vs'kih neoklasikiv. Lublin: Wydawnictwo Uniwersytetu Marii Curie-Skłodowskiej [Сірик Людмила. 2013. Прагнення Свропи. Творчість київских неокласиків. Lublin:Wydawnictwo Uniwersytetu Marii Curie-Skłodowskiej].

Ukraïns'karadâns'ka Enciklopediâ: V sìmnadcâti tomah, t. 10. 1962. Kiïv: Vidavnictvo „Ukraïns'ka Radâns'ka Enciklopediâ” [Українська Радянська Енциклопедія. В сімнадцяти томах, т. 10. 1962. Київ: Видавництво „Українська Радянська Енциклопедія"].

Šapoval Ûrìj. 1990. U tì tragičnì roki: stalìnizm na Ukraïnì. Kï̈v: Polìtvidav Ukraïni [Шаповал Юрій. 1990. У ті трагічні роки: сталінізм на Україні. Київ: Політвидав України].

Gazda Grzegorz. 2000. Stownik europejskich kierunków i grup literackich XX wieku. Warszawa: Wydawnictwo Naukowe PWN.

\section{TRAGIC AND TRAUMATOGENIC CONSEQUENCES OF THE SOVIET POLITICS IN THE FIELD OF UKRAINIAN LITERATURE}

Summary. The article highlights the consequences of the Soviet politics upon Ukrainian literature in the period of 1922-1991. The tragic consequences of the politics are observed at three levels of the cultural trauma, in particular: in the individual biography and creative work of certain representatives of literature, on the background of a public community of the Ukrainians, at the macrosocial level. These problems contribute to the formation of traumatogenic factors, which in their turn negatively affect the development, quality, and popularization of Ukrainian literature.

Keywords: the Soviet politics, Ukrainian literature, totalitarianism, trauma, falsification.

\section{TRAGICZNE I TRAUMATYCZNE SKUTKI POLITYKI RADZIECKIEJ WOBEC LITERATURY UKRAIŃSKIEJ}

Streszczenie. Celem niniejszego artykułu jest ukazanie skutków polityki radzieckiej (okres 1922-1991) wobec literatury ukraińskiej. Autorka konstatuje, że tragiczne skutki polityki radzieckiej na ukraińskiej scenie literackiej może zaobserwować na trzech poziomach traumy kulturowej: a) w indywidualnych biografiach pisarzy oraz ich twórczości; b) na tle wspólnoty społeczeństwa ukraińskiego; c) na płaszczyźnie makrospołecznej. Zidentyfikowane zagadnienia sprzyjają powstawaniu czynników traumatogennych, które z kolei mają też bezpośredni wpływ zarówno na jakość, jak też i popularyzację literatury ukraińskiej.

Słowa klucze: polityka radziecka, literatura ukraińska, totalitaryzm, trauma, falsyfikacja. 